\title{
THE USE OF FDI CRITERIA IN CLINICAL TRIALS ON DIRECT DENTAL RESTORATIONS: A SCOPING REVIEW
}

Marquillier Thomas ${ }^{1}$, Doméjean Sophie ${ }^{2}$, Le Clerc Justine ${ }^{3}$, Chemla Florence ${ }^{4}$, Gritsch Kerstin ${ }^{5}$, Maurin Jean-Christophe ${ }^{5}$, Millet Pierre ${ }^{6}$, Pérard Matthieu $^{3}$, Grosgogeat Brigitte ${ }^{5}$, Dursun Elisabeth ${ }^{7}$

${ }^{1}$ Univ. Lille, CHRU Lille, UFR Odontologie, Odontologie pédiatrique, F-59000 Lille, France; Univ. Paris 13 - Sorbonne Paris Cité, UFR Santé Médecine Biologie Humaine, Laboratoire Educations et Pratiques de Santé (EA 3412), F-93017, France.

${ }^{2}$ Univ Clermont Auvergne, UFR d'Odontologie; CHU Estaing Clermont-Ferrand, Service d'Odontologie, F-63001 Clermont-Ferrand, France; Centre de Recherche en Odontologie Clinique EA 4847, F-63100 Clermont-Ferrand, France.

${ }^{3}$ Univ Rennes1, CHU Rennes, UFR Odontologie, F-35043 Rennes, France; Univ Rennes1, CNRS, U6226, Institut des Sciences Chimiques de Rennes, F-35700 Rennes, France.

${ }^{4}$ Univ. Paris Descartes, APHP Hôpital Charles Foix, UFR Odontologie, F-92120 Montrouge, France.

${ }^{5}$ Univ. Lyon 1, UFR Odontologie, F-69008 Lyon, France; Laboratoire des Multimatériaux et Interfaces, UMR CNRS 5615, F-69008 Lyon, France; Hospices Civils de Lyon, Service de Consultations et de Traitements Dentaires, F-69007, Lyon, France.

${ }^{6}$ Univ. Reims Champagne Ardenne, CHU Reims, Service Odontologie, F-51100 Reims, France.

${ }^{7}$ Univ. Paris Descartes, APHP Hôpital Albert Chenevier, UFR Odontologie, F-92120 Montrouge, France; Univ. Paris Descartes, UFR Odontologie, Unité de recherche en biomatériaux innovants et interfaces (EA4462), F-92120 Montrouge, France.

*Corresponding author:

Pr Brigitte GROSGOGEAT

Faculté d'Odontologie - Université de Lyon

11 rue Guillaume Paradin, 69008 Lyon, France 
Phone: +33478778689

E-mail: brigitte.grosgogeat@univ-lyon1.fr

\section{ABSTRACT}

Objectives: A scoping review was conducted to explore the use of FDI criteria 10 years after their introduction. The first aim was to compare the amount of studies using the FDI and/or the modified USPHS criteria. The second aim was to analyse the use of the FDI criteria in clinical trials evaluating direct dental restorations.

Data: Listing of studies using FDI and/or USPHS criteria per year since 2007. Clinical studies related to the assessment of direct restorations using FDI criteria.

Source: Two systematic searches - regarding the use of FDI and modified USPHS criteria - were carried out on Medline/Pubmed in order to identify the studies published between 2007 and 2017. Authors of the included articles were contacted to clarify their choice of FDI criteria in their studies. ClinicalTrials.gov database was also queried for the on-going studies that use FDI and modified USPHS criteria.

Study selection: In the first review, all the clinical trials (randomized/non-randomized, controlled, prospective/retrospective studies) that used FDI criteria to evaluate direct restorations on primary or permanent teeth were included.

Conclusions: $16.3 \%$ of the studies used FDI criteria. The percentage of studies using them increased from $4.5 \%$ in 2010 to $50.0 \%$ in 2016 . In average, 8.5 FDI criteria were used. The most employed criteria were: marginal adaptation (96.7\%), staining (90.0\%), fracture of material and retention (90.0\%), recurrence of caries/erosion/abfraction (90.0\%), post-operative sensitivity/tooth vitality (86.7\%) and surface luster (60.0\%). In addition, among the 27 on-going studies from ClinicalTrials.gov database, 51.9\% use FDI criteria (including 87.5\% with an open recruitment status). 
Clinical significance: FDI criteria were reported as practical (various and freely selectable), relevant (sensitive as well as appropriate to current restorative materials and clinical studies design), standardized (making comparisons between investigations easier). Investigators should go on using them for a better standardization of their clinical judgment, allowing comparisons with other studies.

Keywords: restorative dentistry; direct dental restorations; FDI criteria; clinical trial; clinical assessment.

\section{INTRODUCTION}

In 1971, Cvar and Ryge proposed five criteria (color match, cavosurface marginal discoloration, anatomic form, marginal adaptation and caries) for the clinical assessment of dental restorations [1]. Those criteria were revised in 1980 and were called "modified Ryge criteria" or "modified United States Public Health Service (USPHS) criteria" [2]. In addition to the initial five criteria, new categories such as occlusion, postoperative sensitivity, fracture, retention and others were taken into account. For each category, different items allow to score the restoration as follows: A (Alpha)- restoration which is clinically ideal, B (Bravo)- restoration showing minor deviations from the ideal but nevertheless acceptable (except for retention and secondary caries), C (Charlie)- restoration which should be replaced for preventive reasons to avoid the likelihood of future damage and D (Delta)- restoration requiring immediate replacement. However, authors did not always use the same definitions to assign the scores. Moreover, the modified USPHS criteria were developed when amalgam restorations were commonly used and when adhesive materials had a limited longevity. In order to make these criteria more selective, researchers had to modify and adapt them, which led to "modified Ryge criteria”. Nevertheless, many restorations continued to receive an alpha score after 12 or 18 months [3, 4].

To detect early deterioration and sign of failures, a more sensitive and discriminative scale than the "modified Ryge criteria" was required and in 2007, Hickel et al proposed a new system based on three criteria categories: aesthetic, functional and biological (Table 1) [3, 4]. Each category was divided into subcategories to allow for more detailed description and analysis. Each subcategory was scored according to a five-step grading of the restoration: score 1- the restoration is excellent/fulfills all quality criteria; score 2- the restoration is still highly acceptable, though 
one or more criteria deviate from the ideal (no risk of damage); score 3- the restoration is sufficiently acceptable but with minor shortcomings; score 4- the restoration is unacceptable but repairable; score 5- the restoration has to be replaced. The final score in each category was the most severe score obtained among all subcategories. The criteria defined by Hickel et al. was approved by the Science Committee of the FDI World Dental Federation in 2007 [3, 4] and considered in 2008 as "Standard Criteria" [5, 6]. Their use was thus recommended in clinical trials assessing dental restorations in terms of materials, operative technique/intervention, as well as in clinical practice to determine whether a restoration should be maintained, repaired or replaced [3,4]. However, the authors outlined that investigators should not necessary use the full set of the 16 criteria but select the most suitable, according to the objectives of their study. Moreover, they added that the five-step grading may also be reduced to foursteps (two acceptable and two unacceptable) or to two-steps by combining scores 1-3 and scores 4 and 5 into respectively "acceptable restoration" and "unacceptable restoration". Then, the first uses and feedbacks led to modifications of some criteria and scores in 2010 [5, 6]. Since then, no update or further feedbacks have been published regarding their application in clinical studies.

A scoping review was conducted to explore the extent of the use of FDI criteria, 10 year after their introduction. The primary aim of this manuscript was to compare the amount of studies using the FDI and/or the modified USPHS criteria. The secondary aim was to analyse the use of the FDI criteria in clinical trials evaluating direct dental restorations.

\section{MATERIALS AND METHODS}

A scoping review was conducted to explore a wide range of literature on the use of the FDI criteria, irrespective of the quality of the studies [7]. Table 2 presents the whole search strategy.

A first systematic electronic search was performed using the keyword "FDI criteria" on Medline/PubMed database. Inclusion criteria were: all the clinical trials (randomized or non-randomized, controlled, prospective and retrospective studies) published between January 2007 to April 2017 that used FDI criteria to evaluate direct restorations on primary or permanent teeth. Exclusion criteria were: in vitro studies, case reports and review articles, as well as publications not written in English language. This systematic search followed the PRISMA statement for reporting [8]. 
The selection of studies was conducted by two independent reviewers (TM and ED). A screening of titles was performed. Irrelevant publications were excluded. Then, the screening of abstracts led to a selection of studies in compliance with the inclusion criteria. Full texts were finally reviewed. In case of disagreement, a consensus was obtained with supervisors (BG and SD). For each paper, the following data - study design, dentition, FDI criteria used in the study, other criteria used if applicable, training and calibration of examiners (Table 3) - were extracted independently and in duplicate by the two reviewers. These data were collected in an Excel spread sheet. In case of disagreement regarding the extraction of data, a consensus was obtained with supervisors (BG and SD). A manual screening was also carried out among the references of selected articles in order to gather further relevant papers.

Corresponding authors of the included articles were contacted by e-mail, to clarify their choice of FDI criteria. They were sent a two-column personalized table. The first column was pre-filled with the criteria they did not use in their study. They were asked to explain the reasons in the second column.

A second systematic electronic search regarding the use of the modified USPHS criteria was performed with a combination of both keywords "USPHS criteria" AND "Ryge criteria” on Medline/Pubmed database to identify studies published between January 2007 and April 2017. Only the number of studies per year was reported to explore in which extend FDI criteria were used in clinical studies since their introduction, compared to USPHS criteria. As this study focuses on FDI criteria, the abstracts and full texts of studies using USPHS were not considered.

Finally, the ClinicalTrials.gov database was also queried for on-going studies using either the FDI criteria or the modified USPHS criteria, with the keywords "FDI criteria", "USPHS criteria" and "Ryge criteria", respectively. The website distinguishes studies with an open recruitment status - such as "recruiting", "not yet recruiting" or "available for expanded access" - and those with a closed recruitment status, including "completed" or "active, not recruiting" studies. The number of on-going studies (in open and closed recruitment) was then reported. Clinical trials exceeding their completion date and those with no verification of the recruitment within the past two years on the website ClinicalTrials.gov are noted as "unknown". In both cases, they were excluded.

\section{RESULTS}




\section{The use of FDI and modified USPHS criteria per year since 2007}

For the first systematic search related to FDI criteria, on the 93 eligible papers, 38 articles were selected after a review of titles and abstracts. Thirty articles were finally included after full reading and manual screening (Figure 1; Table 3) [9-38]. The second systematic search identified 154 studies using the modified USPHS criteria. Figure 2 displays the respective number of studies using FDI criteria, modified USPHS criteria or both, per year since 2007.

Table 4 states the percentage of studies using FDI criteria per year since 2007. The 30 clinical studies using FDI criteria represents $16.3 \%$ of all the conducted studies. Five studies (3.8\%) used both criteria. The first studies using FDI criteria were published in 2010 . The percentage of studies using the FDI criteria increased from $4.5 \%$ in 2010 to $50.0 \%$ in 2016.

Among the 30 studies using FDI criteria, 25 of them were prospective studies [10, 12-15, 17-30, 32-35, 37, 38] and primary teeth were involved in five of them $[10,11,18,31,34]$. In 26 studies, examiners were calibrated [9, 10, 12-30, 32, 33, 35, 36, 38]. Figure 3 showed the percentage of use for each criterion in the 30 selected studies. Only two studies used all the 16 existing FDI criteria [35, 37]. The average number of criteria chosen in all studies was 8.5. The most employed criteria were: marginal adaptation (criterion 6; 29 studies, i.e. $96.7 \%$ of the studies) [9-24, 26-38], staining (criterion 2; 27 studies, i.e. 90.0\% of the studies) [9-18, 20-23, 25-30, 32-38], fracture of material and retention (criterion 5; 27 studies, i.e. $90.0 \%$ of the studies) [9-24, 26, 29-38], recurrence of caries/erosion/abfraction (criterion 12; 27 studies, i.e. $90.0 \%$ of the studies) [9-25, 27, 28, 30, 31, 33-38], post-operative sensitivity and tooth vitality (criterion 11; 26 studies, i.e. 86.7\% of the studies) [10-18, 20, 21, 23-30, $32-38]$ and surface luster (criterion 1; 18 studies, i.e. $60.0 \%$ of the studies) [9, 10, 12-14, 16, 18, 20-24, 29, 32, 34-37]. The least used criteria were: radiographic examination (criterion 9; 6 studies) [10, 11, 18, 34, 35, 37], patient's view (criterion 10; 7 studies) [12, 20, 24, 34-37] and oral and general health (criteria 16, 9 studies) [10, 12, 16, 18, 20, 31, 34, 35, 37].

Among the 27 corresponding authors joined by e-mail, 16 authors answered and explained the reason why they only selected some specific FDI criteria upon the 16 available. In fact, they considered some of them create confusion or lack consistency. They also mentioned that some criteria were not meaningful for their studies. For example, criteria 4, 7-9, 13, 15 and 16 were not relevant enough and/or applicable for the 
evaluation of direct cervical restorations [15, 17, 21, 23, 25-30, 33, 38]. Similarly, criteria 1 and 3 were not either appropriate for the assessment of glass ionomer cement (GIC) restorations [11, 15, 17, 19, 25-28, 30, 33, 38]. In most cases, radiographic examination (criterion 9) was not used for ethical reasons (with a poor risk-benefit ratio for patients) [9, 12-17, 19-33, 36, 38], for administrative reasons or because of the lack of interest in the study. Criteria 10,11, 14 and 15 were also poorly used. Finally, oral and general health (criterion 16) was considered as a confusing element without any real impact on the restoration lifetime.

\section{The use of FDI criteria in on-going studies}

There are 27 on-going studies including 8 with an open recruitment status. 14 use FDI criteria, which represents $51.9 \%$ of the on-going studies. Seven with an open recruitment status use FDI criteria that means $87.5 \%$ of the studies (Figure 4).

\section{Characteristics of the included studies and their management of FDI criteria}

Among the 30 selected studies, 15 different research teams could be identified. Most of the studies were well conducted since they were prospective and randomized with a well-described evaluation procedure. Nevertheless, some authors omitted to properly describe the calibration process of their evaluators. Indeed, according to Hickel et al [3, 4], an appropriate assessment must rely on two independent and calibrated examiners, different from the operators. Moreover, to ensure reproducible results, only experienced evaluators obtaining at least an $85 \%$ concordance rate must be involved in the clinical assessments $[3,4]$. If some studies mentioned the examiner calibration, their training was often not precisely described. Furthermore, calibration appeared to be heterogeneous among surveys. While photographs remained the most widely used tools $[17,21,22,25-27,30,33,38]$, five studies reported the training of evaluators with $e$-calib, an online training and calibration tool for the evaluation of dental restorations [20, 21, 24, 32, 36].

All the studies analysed adhesive materials. Most of them investigated the performance of composite resins (flowable or not, silorane) [16, 23,37 and/or the procedures i.e with chlorhexidine pre-treatment [32], with or without bevel [13, 14], with rubber dam or cotton rolls/retraction cord [26], with various polishing systems [21] and/or the indications (for non-carious cervical lesion, for primary teeth, in anterior or posterior 
position) [9-11, 18, 20, 31, 34-36]. Many other studies evaluated the performance of various adhesive types (etch and rinse, self-etch or universal) $[27,30,33]$ and/or the procedure (with EDTA conditioning) [28] and/or the indications (for non-carious cervical lesions) [12, 15, 17, 38]. Finally, other materials and techniques, such as the GIC [24] or the atraumatic restorative treatment (ART) technique were examined [19].

\section{DISCUSSION}

The present review explores the use of FDI criteria since their introduction in 2007.

\section{FDI criteria versus modified USPHS criteria}

FDI criteria are little used compared to the modified USPHS criteria (30 and 154 published studies, respectively). Nevertheless, a significant increase in the use of FDI criteria has been observed since 2010, the year of the first publication, reaching $50 \%$ of the published studies in 2016. In the same way, among the 27 currently on-going studies, more than a half (51.9\%) based their assessment on FDI criteria and $87.5 \%$ of those with an open recruitment status used them. This shows an increasing interest for FDI criteria. Their widespread use would allow standardization for the evaluation of restorations, which would make comparisons between studies easier and even enable meta-analysis.

In fact, outcomes of clinical trials for the same health condition/intervention are often inconsistently measured or reported. They are also too technical and clinician-centered [39]. Yet, they need to be relevant to patients. The development of core outcome sets (COS) has been suggested to address these issues [40,41]. As COS is an agreed standardized collection of outcomes, the comparison or combination of the results of trials and synthesis of data become thus possible. This strengthens the overall evidence base and improves clinical practice. In restorative dentistry, Lamont et al. and Schwendicke et al. reported the need and the initial steps to develop a COS for prevention and caries management trials [42, 43]. In the same way, FDI criteria could be considered as a COS for trials, which assesses dental restorations. However, as some criteria were considered as poor relevant or not applicable in some studies, it would be necessary to discuss the mandatory nature of each FDI criteria and perhaps to define a COS with only the absolute necessary and tangible criteria for all studies and not on the current 16 criteria. An update of the use of FDI criteria 
and discussions about its use as a COS with a new meeting of the World Dental Federation would be beneficial. Finally, FDI criteria also involve a patient-centred criterion (criterion 10, "patient view"), which is an added value compared to modified USPHS criteria.

\section{Interest of the FDI criteria}

In addition to the benefits mentioned above, the FDI criteria-based proposal allows to classify the evaluation of dental restorations, according to functional, biological and aesthetic categories. The higher number of scores (1 to 5) - compared to the USPHS criteria - was reported to make easier the ability of discerning potential differences in the quality of restorations [13,14], which overall increases the quality of assessments. Nevertheless, some studies ( 3 among the 30 of the first systematic research) did not use the 5 scores $[15,16,36]$, and one (a retrospective study) did not even mention the number of scores used [31] (Table 3).

As previously indicated, among the 16 purposed criteria, the authors can select the most appropriate criteria for their study. They may also adapt the use of the selected criteria, as Bektas Donmez et al. did in their study regarding clinical performance of restorative materials in primary teeth [10]. In that study, the authors adapted both criteria - "proximal contact point" and "radiographic examination" - because of the specific features of primary teeth, i.e. the lack of a contact point inducing food retention and the specific precautions to be taken for children.

In the study of Kim et al based upon a photographic evaluation of posterior tooth-colored restorations, FDI criteria present a high intraexaminer and a slight to fair inter-examiner reliability, that may be increased by the simplification of the evaluation scores [22]. Some studies (23.3\%) used both FDI and modified USPHS criteria allowing a comparison between them [17, 20, 25, 27, 30, 33, 36]. FDI criteria seemed to be more sensitive and precise compared to the modified USPHS criteria, with regards to minor differences in the clinical outcomes, especially in studies assessing non-carious cervical lesion restorations [17, 27, 30, 33] or for the "marginal adaptation" [25, 33] and "marginal staining" criteria [25]. However, the FDI criteria might be less reliable, encouraging some authors to reduce the number of scores used.

\section{Selection of the FDI criteria}


As recommended by Hickel et al [5,6], most of the studies did not use all criteria. To explain their choice of the criteria used, the authors indicate that they selected them according to the type and the aims of their study as recommended by Hickel et al. [5, 6]. The most used criteria were those already evaluated by modified USPHS criteria, such as marginal adaptation (criterion 6; 96.7\% of the studies), staining (criterion 2;

$90.0 \%$ of the studies), recurrence of caries/erosion/abfraction (criterion 12; $90.0 \%$ of the studies) and post-operative sensitivity and tooth vitality (criterion 11; 86.7\% of the studies), because they are critical for the assessment of the quality of restorations. Three were much less used (in less than $30 \%$ of studies): radiographic examination (criterion 9, 20.0\%), the patient's view (criterion 10, 23.3\%) and adjacent mucosa (criteria 15, 26.7\%). In fact, investigators often estimated the benefit/risk ratio for the radiographic examination too low, in particular in the studies conducted in children, and both following criteria, patient's view and adjacent mucosa, not essential for the evaluation.

\section{Limitations of the study}

As this present work is related to the "Deep Caries Treatment (DECAT)" study, which evaluates direct restorations [44], it was decided to restrict the search to the studies related to direct dental restorations and to exclude all the others. However, the same work with indirect restorations would bring additional information and should be subject to further investigation.

As only Pubmed database was checked and only publications written in English language were selected, potentially relevant papers could have been missed.

\section{CONCLUSION}

FDI criteria were reported as practical (various and freely selectable criteria), relevant (sensitive as well as appropriate to current restorative materials and clinical studies design), standardized (making comparisons between different investigations easier). Their use depends on the objectives of the studies (use of 8.5 criteria in average among the 16 available). All the recommendations of Hickel et al $[3,4]$ regarding their use, their selection, the calibration of examiners were globally followed. A significant increase of the use of FDI criteria, compared to the modified 
USPHS criteria, has been observed since 2010, thereafter reaching 50\% of the published studies in 2016. Investigators should go on using the FDI criteria for a better standardization of their clinical judgment on restorations, allowing comparisons with all other studies.

\section{ACKNOWLEDGMENTS}

- To the DECAT collaborative group, especially the team of Pr Gueyffier (coordination) and the Hospices Civils of Lyon (sponsor) This review is in relation with the DECAT study (DEep Caries Treatment). This clinical trial received a PHRC grant (which is a French funding source for hospital clinical trial) from the ministry of health (DGOS). This funding source had neither involvement in the study design, in the analysis, collection and interpretation of data nor in the writing of this manuscript.

\section{- To the corresponding authors of the included studies, who answered the questionnaire}

- To Maxime Faure, who contributed to this publication as part of his end-of-studies thesis in Dental Surgery (University Lyon 1, France)

- To Misha Dhuper (University of Ottawa), who reviewed the English language in this manuscript. 


\section{REFERENCES}

[1] J.F. Cvar, G. Ryge, Reprint of criteria for the clinical evaluation of dental restorative materials. 1971, Clin Oral Investig 9(4) (2005) $215-32$.

[2] G. Ryge, Clinical criteria, International dental journal 30(4) (1980) 347-58.

[3] R. Hickel, J.F. Roulet, S. Bayne, S.D. Heintze, I.A. Mjor, M. Peters, V. Rousson, R. Randall, G. Schmalz, M. Tyas, G. Vanherle, Recommendations for conducting controlled clinical studies of dental restorative materials, Clin Oral Investig 11(1) (2007) 5-33.

[4] R. Hickel, J.F. Roulet, S. Bayne, S.D. Heintze, I.A. Mjor, M. Peters, V. Rousson, R. Randall, G. Schmalz, M. Tyas, G. Vanherle, Recommendations for conducting controlled clinical studies of dental restorative materials. Science Committee Project 2/98--FDI World Dental Federation study design (Part I) and criteria for evaluation (Part II) of direct and indirect restorations including onlays and partial crowns, J Adhes Dent 9 Suppl 1 (2007) 121-47.

[5] R. Hickel, A. Peschke, M. Tyas, I. Mjor, S. Bayne, M. Peters, K.A. Hiller, R. Randall, G. Vanherle, S.D. Heintze, FDI World Dental Federation: clinical criteria for the evaluation of direct and indirect restorations-update and clinical examples, Clin Oral Investig 14(4) (2010) 349-66.

[6] R. Hickel, A. Peschke, M. Tyas, I. Mjor, S. Bayne, M. Peters, K.A. Hiller, R. Randall, G. Vanherle, S.D. Heintze, FDI World Dental Federation - clinical criteria for the evaluation of direct and indirect restorations. Update and clinical examples, J Adhes Dent 12(4) (2010) $259-72$.

[7] H. Arksey, L. O’Malley, Scoping studies: towards a methodological framework, Int J Social Res Methodol 8(1) (2005) 19-32.

[8] D. Moher, L. Shamseer, M. Clarke, D. Ghersi, A. Liberati, M. Petticrew, P. Shekelle, L.A. Stewart, P.-P. Group, Preferred reporting items for systematic review and meta-analysis protocols (PRISMA-P) 2015 statement, Syst Rev 4 (2015) 1.

[9] R.A. Baldissera, M.B. Correa, H.S. Schuch, K. Collares, G.G. Nascimento, P.S. Jardim, R.R. Moraes, N.J. Opdam, F.F. Demarco, Are there universal restorative composites for anterior and posterior teeth?, J Dent 41(11) (2013) 1027-35.

[10] S. Bektas Donmez, S. Uysal, A. Dolgun, M.D. Turgut, Clinical performance of aesthetic restorative materials in primary teeth according to the FDI criteria, Eur J Paediatr Dent 17(3) (2016) 202-212. 
[11] K. Bucher, I. Metz, V. Pitchika, R. Hickel, J. Kuhnisch, Survival characteristics of composite restorations in primary teeth, Clin Oral Investig 19(7) (2015) 1653-62.

[12] E.U. Celik, B. Aka, F. Yilmaz, Six-month clinical evaluation of a self-adhesive flowable composite in noncarious cervical lesions, J Adhes Dent 17(4) (2015) 361-8.

[13] F.H. Coelho-de-Souza, C.A. Klein-Junior, J.C. Camargo, T. Beskow, M.D. Balestrin, F.F. Demarco, Double-blind randomized clinical trial of posterior composite restorations with or without bevel: 6-month follow-up, J Contemp Dent Pract 11(2) (2010) 001-8.

[14] F.H. Coelho-De-Souza, J.C. Camargo, T. Beskow, M.D. Balestrin, C.A. Klein-Junior, F.F. Demarco, A randomized double-blind clinical trial of posterior composite restorations with or without bevel: 1-year follow-up, J Appl Oral Sci 20(2) (2012) 174-9.

[15] T.R. da Costa, L.D. Ferri, A.D. Loguercio, A. Reis, Eighteen-month randomized clinical trial on the performance of two etch-and-rinse adhesives in non-carious cervical lesions, Am J Dent 27(6) (2014) 312-7.

[16] P.A. Da Rosa Rodolpho, T.A. Donassollo, M.S. Cenci, A.D. Loguercio, R.R. Moraes, E.M. Bronkhorst, N.J. Opdam, F.F. Demarco, 22-Year clinical evaluation of the performance of two posterior composites with different filler characteristics, Dent Mater 27(10) (2011) 955-63.

[17] E.A. de Paula, L.Y. Tay, C. Kose, A. Mena-Serrano, A. Reis, J. Perdigao, A.D. Loguercio, Randomized clinical trial of four adhesion strategies in cervical lesions: 12-month results, Int J Esthet Dent 10(1) (2015) 122-45.

[18] S.B. Donmez, M.D. Turgut, S. Uysal, P. Ozdemir, M. Tekcicek, B. Zimmerli, A. Lussi, Randomized clinical trial of composite restorations in primary teeth: effect of adhesive system after three years, Biomed Res Int 2016 (2016) 5409392.

[19] A. Farag, W.J. van der Sanden, H. Abdelwahab, J.E. Frencken, Survival of ART restorations assessed using selected FDI and modified ART restoration criteria, Clin Oral Investig 15(3) (2011) 409-15.

[20] C. Frese, P. Schiller, H.J. Staehle, D. Wolff, Recontouring teeth and closing diastemas with direct composite buildups: a 5-year follow-up, J Dent 41(11) (2013) 979-85.

[21] J.H. Jang, H.Y. Kim, S.M. Shin, C.O. Lee, D.S. Kim, K.K. Choi, S.Y. Kim, Clinical effectiveness of different polishing systems and self-etch adhesives in class V composite resin restorations: two-year randomized controlled clinical trial, Oper Dent 42(1) (2017) 19-29. 
[22] D. Kim, S.Y. Ahn, J. Kim, S.H. Park, Interrater and intrarater reliability of FDI criteria applied to photographs of posterior tooth-colored restorations, J Prosthet Dent (2016).

[23] Y. Kitasako, A. Sadr, M.F. Burrow, J. Tagami, Thirty-six month clinical evaluation of a highly filled flowable composite for direct posterior restorations, Aust Dent J 61(3) (2016) 366-73.

[24] T. Klinke, A. Daboul, A. Turek, R. Frankenberger, R. Hickel, R. Biffar, Clinical performance during 48 months of two current glass ionomer restorative systems with coatings: a randomized clinical trial in the field, Trials 17(1) (2016) 239.

[25] A.D. Loguercio, E.A. de Paula, V. Hass, I. Luque-Martinez, A. Reis, J. Perdigao, A new universal simplified adhesive: 36-Month randomized double-blind clinical trial, J Dent 43(9) (2015) 1083-92.

[26] A.D. Loguercio, I. Luque-Martinez, A.H. Lisboa, C. Higashi, V.A. Queiroz, R.O. Rego, A. Reis, Influence of isolation method of the operative field on gingival damage, patients' preference, and restoration retention in noncarious cervical lesions, Oper Dent 40(6) (2015) $581-93$.

[27] L.S. Lopes, F.S. Calazans, R. Hidalgo, L.L. Buitrago, F. Gutierrez, A. Reis, A.D. Loguercio, M.O. Barceleiro, Six-month follow-up of cervical composite restorations placed with a new universal adhesive system: a randomized clinical trial, Oper Dent 41(5) (2016) 465-480.

[28] I. Luque-Martinez, M.A. Munoz, A. Mena-Serrano, V. Hass, A. Reis, A.D. Loguercio, Effect of EDTA conditioning on cervical restorations bonded with a self-etch adhesive: A randomized double-blind clinical trial, J Dent 43(9) (2015) 1175-83.

[29] S. May, F. Cieplik, K.A. Hiller, W. Buchalla, M. Federlin, G. Schmalz, Flowable composites for restoration of non-carious cervical lesions: Three-year results, Dent Mater (2017).

[30] A. Mena-Serrano, C. Kose, E.A. De Paula, L.Y. Tay, A. Reis, A.D. Loguercio, J. Perdigao, A new universal simplified adhesive: 6-month clinical evaluation, J Esthet Restor Dent 25(1) (2013) 55-69.

[31] I. Metz, K. Rothmaier, V. Pitchika, A. Crispin, R. Hickel, F. Garcia-Godoy, K. Bucher, J. Kuhnisch, Risk factors for secondary caries in direct composite restorations in primary teeth, Int J Paediatr Dent 25(6) (2015) 451-61.

[32] A.F. Montagner, A.P. Perroni, M.B. Correa, A.S. Masotti, T. Pereira-Cenci, M.S. Cenci, Effect of pre-treatment with chlorhexidine on the retention of restorations: a randomized controlled trial, Braz Dent J 26(3) (2015) 234-41. 
[33] J. Perdigao, C. Kose, A.P. Mena-Serrano, E.A. De Paula, L.Y. Tay, A. Reis, A.D. Loguercio, A new universal simplified adhesive: 18-month clinical evaluation, Oper Dent 39(2) (2014) 113-27.

[34] F. Sengul, T. Gurbuz, Clinical evaluation of restorative materials in primary teeth class II lesions, J Clin Pediatr Dent 39(4) (2015) 315-21.

[35] J.A. Skupien, M.S. Cenci, N.J. Opdam, C.M. Kreulen, M.C. Huysmans, T. Pereira-Cenci, Crown vs. composite for post-retained restorations: A randomized clinical trial, J Dent 48 (2016) 34-9.

[36] H.J. Staehle, T. Wohlrab, D. Saure, D. Wolff, C. Frese, A 6.5-year clinical follow-up of direct resin composite buildups in the posterior dentition: Introduction of a new minimally invasive restorative method, J Dent 43(10) (2015) 1211-7.

[37] R. Walter, L.W. Boushell, H.O. Heymann, A.V. Ritter, J.R. Sturdevant, A.D. Wilder, Jr., Y. Chung, E.J. Swift, Jr., Three-year clinical evaluation of a silorane composite resin, J Esthet Restor Dent 26(3) (2014) 179-90.

[38] C. Zander-Grande, R.C. Amaral, A.D. Loguercio, L.P. Barroso, A. Reis, Clinical performance of one-step self-etch adhesives applied actively in cervical lesions: 24-month clinical trial, Oper Dent 39(3) (2014) 228-38.

[39] P.S. Fleming, D. Koletsi, K. O'Brien, A. Tsichlaki, N. Pandis, Are dental researchers asking patient-important questions? A scoping review. J Dent. 2016 Jun;49:9-13, J Dent 49 (2016) 9-13.

[40] M. Clarke, Standardising outcomes for clinical trials and systematic reviews, Trials 8 (2007) 39.

[41] A. Chiarotto, R.W. Ostelo, D.C. Turk, R. Buchbinder, M. Boers, Core outcome sets for research and clinical practice, Braz J Phys Ther 21(2) (2017) 77-84.

[42] T. Lamont, F. Schwendicke, N. Innes, Why we need a core outcome set for trials of interventions for prevention and management of caries, Evid Based Dent 16(3) (2015) 66-8.

[43] F. Schwendicke, T. Lamont, N. Innes, Outcomes in trials for management of caries lesions (OuTMaC): protocol, Trials 16(1) (2015) 397.

[44] C. Villat, J.P. Attal, N. Brulat, F. Decup, S. Domejean, E. Dursun, H. Fron-Chabouis, B. Jacquot, M. Muller Bolla, N. Plasse-Pradelle, L. Roche, D. Maucort-Boulch, P. Nony, K. Gritsch, P. Millet, F. Gueyffier, B. Grosgogeat, One-step partial or complete caries removal and bonding with antibacterial or traditional self-etch adhesives: study protocol for a randomized controlled trial, Trials 17 (2016) 404. 
Figure captions

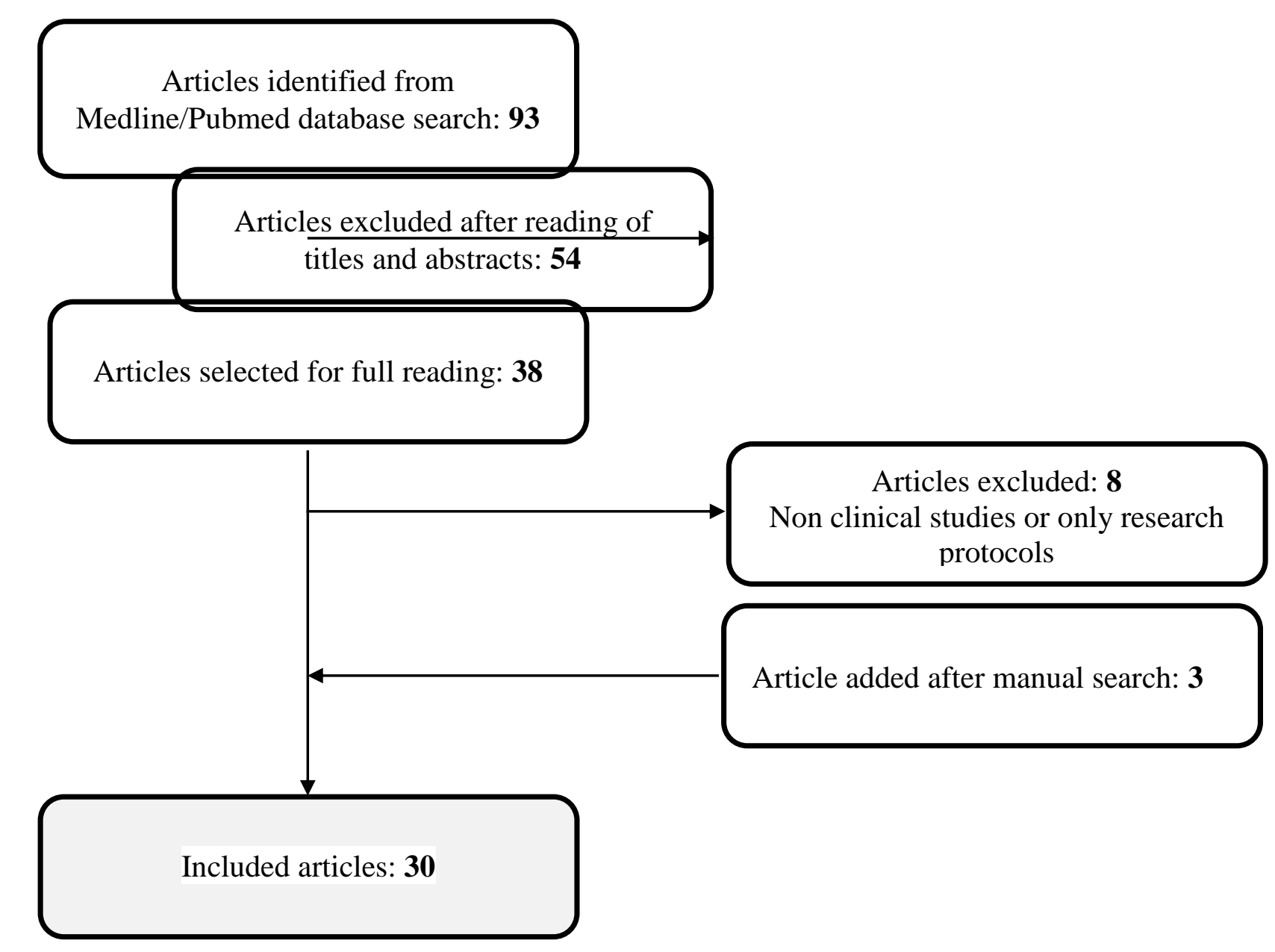


Figure 1: Flowchart of the selection process for the first systematic search regarding the use of FDI criteria

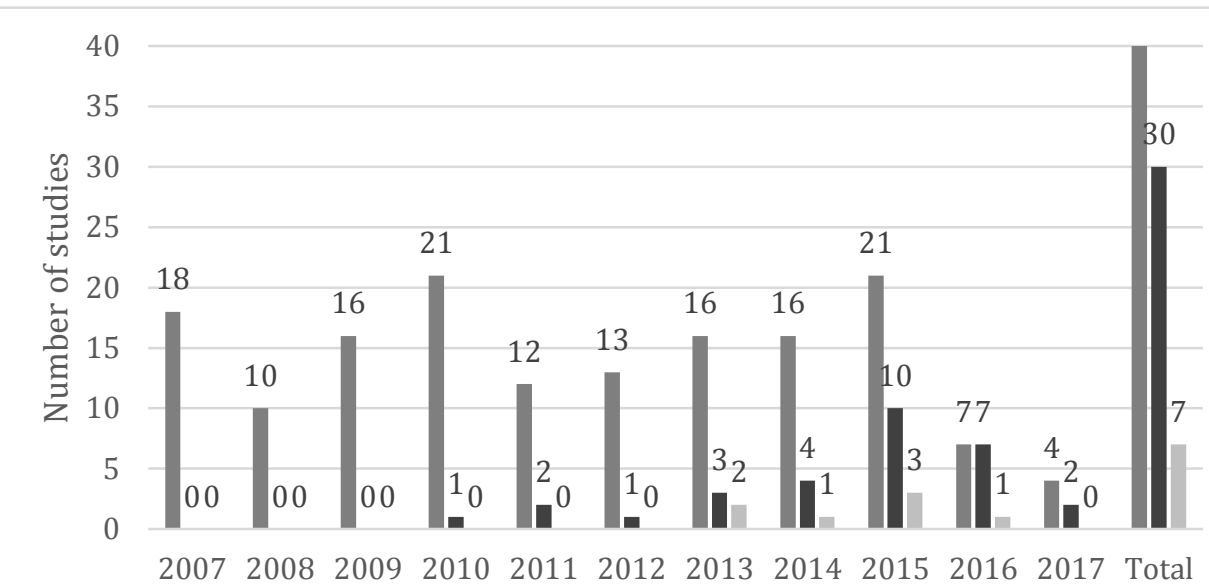

Year 


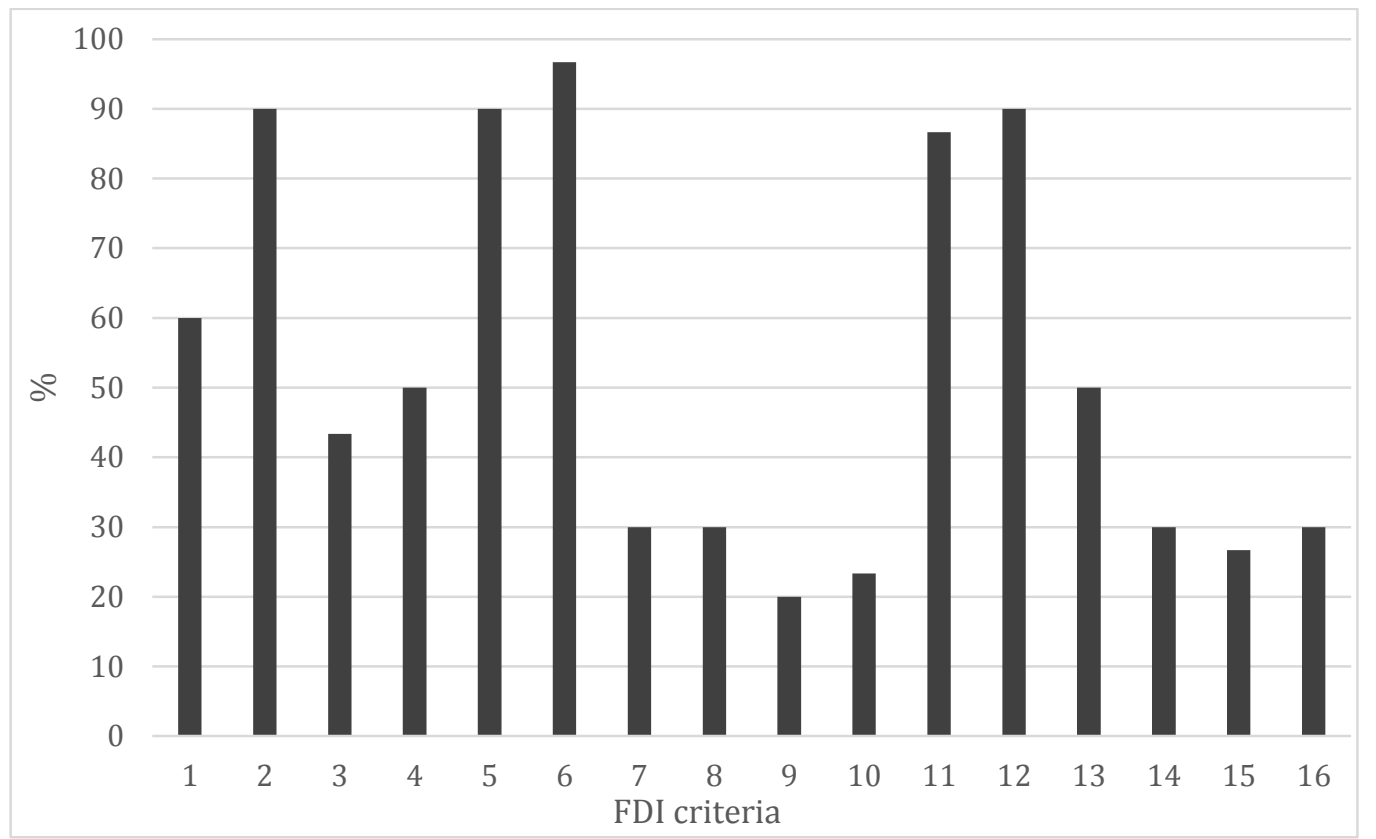

Figure 3: Percentage of use for each criterion in the 30 selected studies (for each criterion, from 1 to 16: "number of studies using the criterion"/"the total number of studies $(\mathrm{n}=30)$ ") 


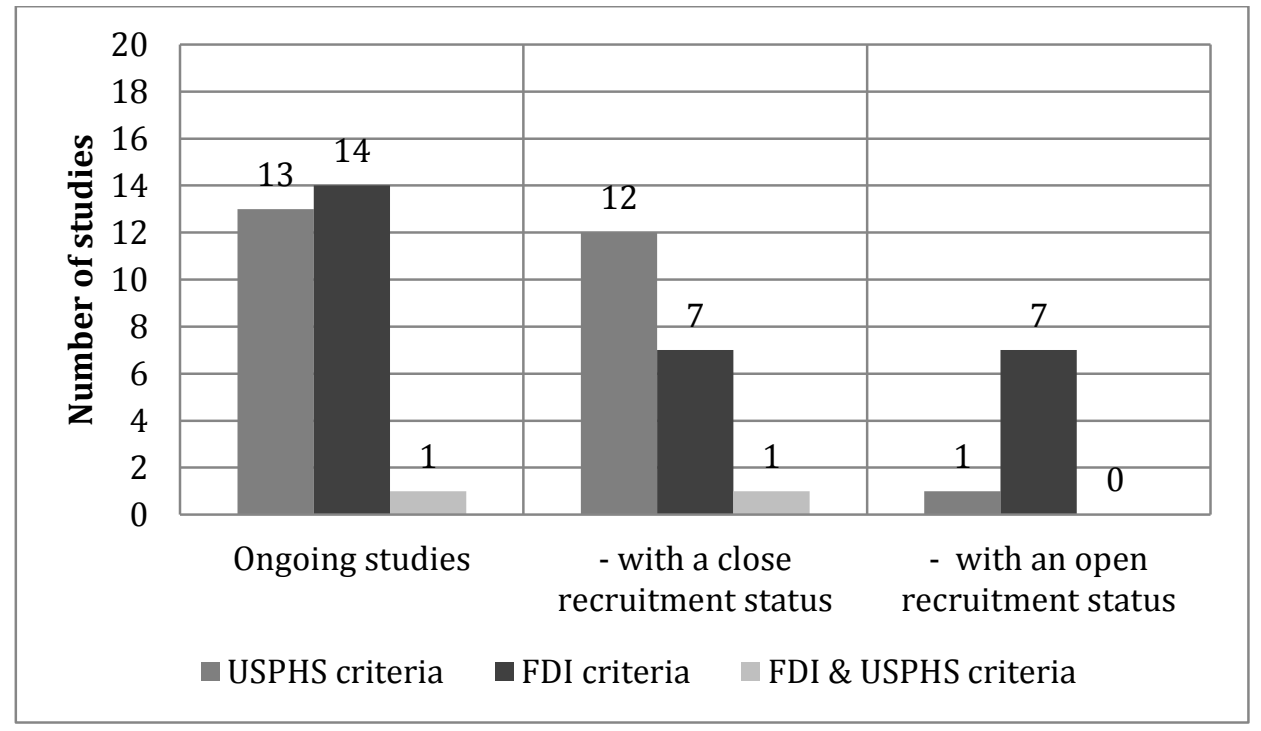

Figure 4: Number of on-going studies using FDI criteria, USPHS criteria and both, including those with a close recruitment status and those with an open recruitment status 
Table 1: The FDI criteria with their various categories and their grading (in italic: the revisions of 2010), and the correspondence with the USPHS criteria, with their various criteria and their grading (in italic: the modified USPHS)

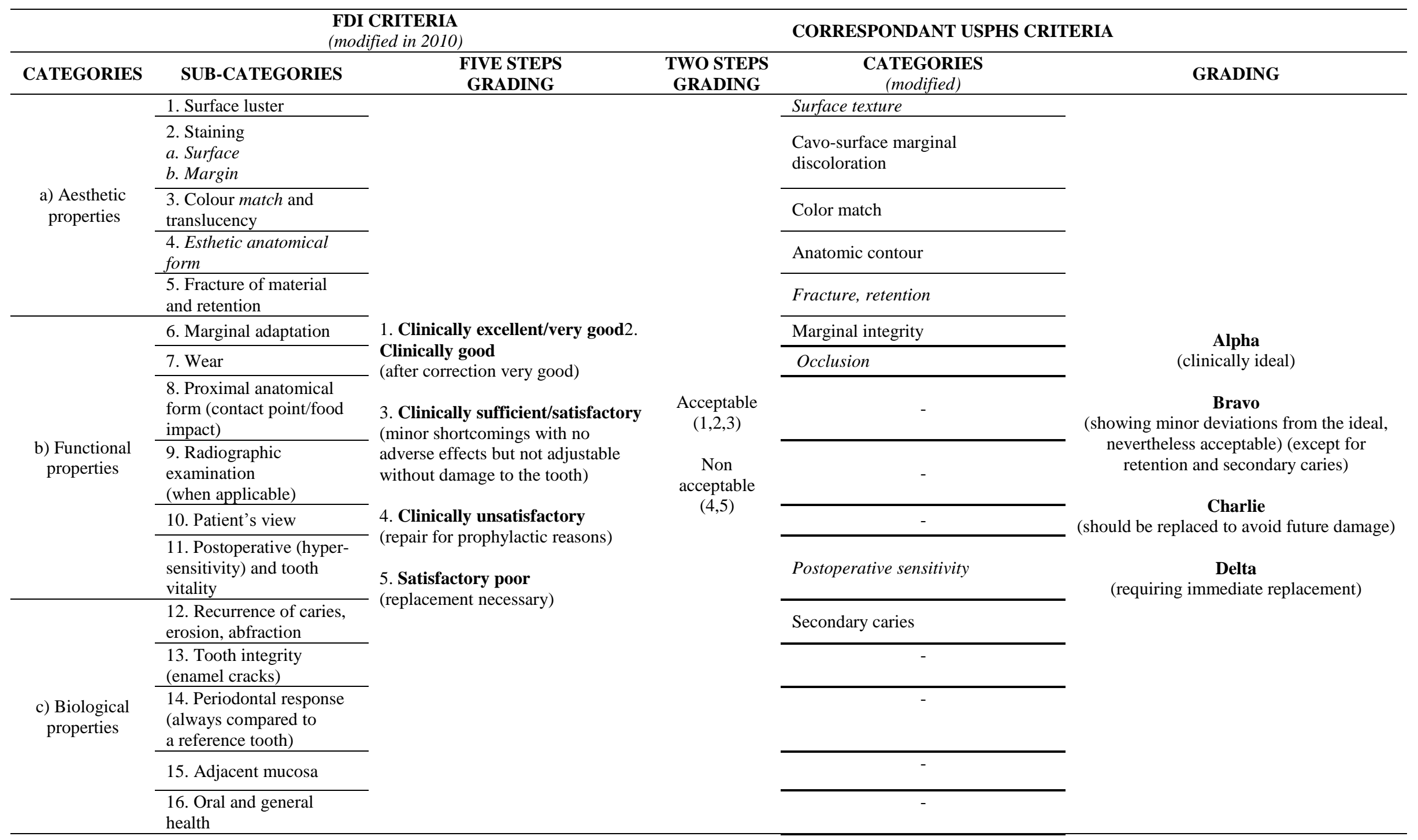


Table 2: Search strategy of the scoping review to explore the extent of the use of FDI criteria

\begin{tabular}{|c|c|c|c|c|}
\hline Review type and objectives & Database & $\begin{array}{c}\text { Combination of } \\
\text { key-words }\end{array}$ & Exclusion criteria & Date filter \\
\hline $\begin{array}{l}\text { First systematic review: } \\
\text { - to identify } \\
\text { - to analyse } \\
\text { all the clinical studies using } \\
\text { FDI criteria }\end{array}$ & Pubmed & FDI criteria & - & From January 2007 to April 2017 \\
\hline Supplementary information & $\begin{array}{l}\text { E-mail to the } \\
\text { corresponding } \\
\text { authors }\end{array}$ & - & - & - \\
\hline $\begin{array}{l}\text { Second systematic review: } \\
\text { to identify all the clinical } \\
\text { studies using USPHS criteria }\end{array}$ & Pubmed & $\begin{array}{l}\text { "USPHS criteria" } \\
\text { AND "Ryge criteria" }\end{array}$ & - & From January 2007 to April 2017 \\
\hline \multirow{3}{*}{$\begin{array}{l}\text { Additional search: } \\
\text { to identify all the on-going } \\
\text { clinical studies using FDI and } \\
\text { USPHS criteria }\end{array}$} & \multirow{3}{*}{ ClinicalTrials.gov } & FDI criteria & "Unknown" status & - \\
\hline & & "USPHS criteria" & "Unknown" status & - \\
\hline & & "Ryge criteria" & "Unknown" status & - \\
\hline
\end{tabular}


Table 3: Included studies, their main characteristics and information about the use of FDI criteria

\begin{tabular}{|c|c|c|c|c|c|c|c|c|}
\hline Authors & Year & Article titles & Study characteristics & Dentition & FDI criteria used* & $\begin{array}{l}\text { Number of } \\
\text { score used }\end{array}$ & $\begin{array}{c}\text { Other criteria } \\
\text { used }\end{array}$ & $\begin{array}{c}\text { Examiner } \\
\text { training/calibration }\end{array}$ \\
\hline $\begin{array}{c}\text { Baldissera } e t \\
\text { al } \\
{[9]}\end{array}$ & 2013 & $\begin{array}{l}\text { Are there universal } \\
\text { restorative composites for } \\
\text { anterior and posterior } \\
\text { teeth? }\end{array}$ & Retrospective study & Permanent & $1-8,12,13$ & 5 & - & Trained and calibrated \\
\hline $\begin{array}{c}\text { Bektas } \\
\text { Donmez et al } \\
{[10]}\end{array}$ & 2016 & $\begin{array}{l}\text { Clinical performance } \\
\text { of aesthetic restorative } \\
\text { materials in primary teeth } \\
\text { according } \\
\text { to the FDI criteria }\end{array}$ & $\begin{array}{l}\text { Prospective study } \\
\text { Split-mouth design }\end{array}$ & Primary & $1-6,8,9,11-13,15,16$ & 5 & - & - \\
\hline $\begin{array}{l}\text { Bücher et al } \\
\quad[11]\end{array}$ & 2015 & $\begin{array}{l}\text { Survival characteristics of } \\
\text { composite restorations in } \\
\text { primary teeth }\end{array}$ & Retrospective study & Primary & $2-6,9,11-14$ & 5 & - & - \\
\hline $\begin{array}{l}\text { Çelik et al } \\
\text { [12] }\end{array}$ & 2015 & $\begin{array}{l}\text { Six-month clinical } \\
\text { evaluation of a self- } \\
\text { adhesive flowable } \\
\text { composite in noncarious } \\
\text { cervical lesions }\end{array}$ & $\begin{array}{l}\text { Randomized, controlled, } \\
\text { single-center, prospective } \\
\text { study } \\
\text { Split-mouth design }\end{array}$ & Permanent & $1-7,10-16$ & 5 & - & Trained and calibrated \\
\hline $\begin{array}{l}\text { Coelho-de- } \\
\text { Souza et al } \\
\quad[13]\end{array}$ & 2010 & $\begin{array}{l}\text { Double-blind randomized } \\
\text { clinical trial of posterior } \\
\text { composite restorations } \\
\text { with and without bevel: } \\
\text { 6-month follow-up }\end{array}$ & $\begin{array}{l}\text { Randomized, double-blind, } \\
\text { prospective study } \\
\text { Split-mouth design }\end{array}$ & Permanent & $1,2,4-6,11,12$ & 5 & - & Calibrated \\
\hline $\begin{array}{l}\text { Coelho-de- } \\
\text { Souza et al } \\
\quad[14]\end{array}$ & 2012 & $\begin{array}{l}\text { A randomized double- } \\
\text { blind clinical trial of } \\
\text { posterior composite } \\
\text { restorations with or } \\
\text { without bevel: } 1 \text {-year } \\
\text { follow-up } \\
\end{array}$ & $\begin{array}{l}\text { Randomized, double-blind, } \\
\text { prospective study } \\
\text { Split-mouth design }\end{array}$ & Permanent & $1,2,4-6,11,12$ & 5 & - & Calibrated \\
\hline $\begin{array}{c}\text { Da Costa et al } \\
{[15]}\end{array}$ & 2014 & $\begin{array}{l}\text { Eighteen-month } \\
\text { randomized clinical trial } \\
\text { on the performance of } \\
\text { two etch-and-rinse } \\
\text { adhesives in non-carious } \\
\text { cervical lesions }\end{array}$ & $\begin{array}{l}\text { Randomized, double-blind, } \\
\text { clinical trial }\end{array}$ & Permanent & $2,5,6,11,12$ & 4 & - & Trained and calibrated \\
\hline
\end{tabular}




\begin{tabular}{|c|c|c|c|c|c|c|c|c|}
\hline $\begin{array}{c}\text { Da Rosa } \\
\text { Rodolpho et } \\
\text { al } \\
{[16]}\end{array}$ & 2011 & $\begin{array}{l}\text { 22-Year clinical } \\
\text { evaluation of the } \\
\text { performance of two } \\
\text { posterior composites with } \\
\text { different filler } \\
\text { characteristics }\end{array}$ & Retrospective study & Permanent & $1-8,11-16$ & 4 & - & - \\
\hline $\begin{array}{c}\text { De Paula et al } \\
\text { [17] }\end{array}$ & 2015 & $\begin{array}{l}\text { Randomized clinical trial } \\
\text { of four adhesion } \\
\text { strategies } \\
\text { in cervical lesions: } 12- \\
\text { month results } \\
\end{array}$ & $\begin{array}{l}\text { Randomized, double-blind, } 1 \\
\text { prospective study }\end{array}$ & Permanent & $2,5,6,11,12$ & 5 & $\begin{array}{c}\text { Modified } \\
\text { USPHS criteria }\end{array}$ & Trained on photographs \\
\hline $\begin{array}{c}\text { Bektas } \\
\text { Donmez et al } \\
{[18]}\end{array}$ & 2016 & $\begin{array}{c}\text { Randomized clinical trial } \\
\text { of composite restorations } \\
\text { in primary teeth: effect of } \\
\text { adhesive system after } \\
\text { three years }\end{array}$ & $\begin{array}{l}\text { Randomized, prospective } \\
\text { study }\end{array}$ & Primary & $1-6,8,9,11-13,15,16$ & 5 & - & Trained on photographs \\
\hline $\begin{array}{l}\text { Farag et al } \\
\quad[19]\end{array}$ & 2011 & $\begin{array}{c}\text { Survival of ART } \\
\text { restorations assessed } \\
\text { using selected FDI and } \\
\text { modified ART restoration } \\
\text { criteria } \\
\end{array}$ & Prospective study & Permanent & $5-7,12,13$ & 5 & - & Calibrated \\
\hline $\begin{array}{l}\text { Frese } \text { et al } \\
\quad[20]\end{array}$ & 2013 & $\begin{array}{l}\text { Recontouring teeth and } \\
\text { closing diastemas with } \\
\text { direct composite } \\
\text { buildups: a 5-year follow- } \\
\text { up } \\
\end{array}$ & Prospective study & Permanent & $1-8,10-16$ & 5 & $\begin{array}{c}\text { Modified } \\
\text { USPHS criteria }\end{array}$ & E-calib \\
\hline $\begin{array}{l}\text { Jang et al } \\
\quad[21]\end{array}$ & 2017 & $\begin{array}{l}\text { Clinical effectiveness of } \\
\text { different polishing } \\
\text { systems and self-etch } \\
\text { adhesives in class V } \\
\text { composite resin } \\
\text { restorations: two-year } \\
\text { randomized controlled } \\
\text { clinical trial }\end{array}$ & $\begin{array}{l}\text { Randomized, prospective } \\
\text { study }\end{array}$ & Permanent & $1,2,5,6,11,12$ & 5 & - & $\begin{array}{l}\text { Trained on photographs } \\
\text { and e-calib }\end{array}$ \\
\hline $\begin{array}{c}\text { Kim et al } \\
\quad[22]\end{array}$ & 2016 & $\begin{array}{l}\text { Interrater and intrarater } \\
\text { reliability of FDI criteria } \\
\text { applied to photographs of } \\
\text { posterior tooth-colored } \\
\text { restorations }\end{array}$ & Photographic evaluation & Permanent & $1-6,12,13$ & 5 & - & Trained on photographs \\
\hline
\end{tabular}




\begin{tabular}{|c|c|c|c|c|c|c|c|c|}
\hline $\begin{array}{c}\text { Kitasako et al } \\
{[23]}\end{array}$ & 2016 & $\begin{array}{l}\text { Thirty-six month clinical } \\
\text { evaluation of a highly } \\
\text { filled flowable composite } \\
\text { for direct posterior } \\
\text { restorations }\end{array}$ & $\begin{array}{l}\text { Randomized, prospective } \\
\text { study }\end{array}$ & Permanent & $1,2,5,6,11,12$ & 5 & - & Calibrated \\
\hline $\begin{array}{l}\text { Klinke et al } \\
\text { [24] }\end{array}$ & 2016 & $\begin{array}{l}\text { Clinical performance } \\
\text { during } 48 \text { months of two } \\
\text { current glass ionomer } \\
\text { restorative systems with } \\
\text { coatings: a randomized } \\
\text { clinical trial in the field }\end{array}$ & Prospective study & Permanent & $1,5-8,10-13$ & 5 & - & $\begin{array}{c}\text { Trained/calibrated on E- } \\
\text { calib }\end{array}$ \\
\hline $\begin{array}{c}\text { Loguercio et } \\
\text { al } \\
{[25]}\end{array}$ & 2015 & $\begin{array}{c}\text { A new universal } \\
\text { simplified adhesive: } 36- \\
\text { Month randomized } \\
\text { double-blind clinical trial }\end{array}$ & $\begin{array}{l}\text { Double-blind, prospective } \\
\text { study }\end{array}$ & Permanent & $2,11,12$ & 5 & $\begin{array}{c}\text { Modified } \\
\text { USPHS criteria }\end{array}$ & Trained on photographs \\
\hline $\begin{array}{c}\text { Loguercio et } \\
\text { al } \\
{[26]}\end{array}$ & 2015 & $\begin{array}{l}\text { Influence of isolation } \\
\text { method of the operative } \\
\text { field on gingival damage, } \\
\text { patients' preference, and } \\
\text { restoration retention in } \\
\text { noncarious cervical } \\
\text { lesions }\end{array}$ & $\begin{array}{c}\text { Examiner-blind, } \\
\text { randomized, prospective } \\
\text { study } \\
\text { Split-mouth design }\end{array}$ & Permanent & $2,5,6,11$ & 5 & - & Trained on photographs \\
\hline $\begin{array}{l}\text { Lopes et al } \\
\text { [27] }\end{array}$ & 2016 & $\begin{array}{l}\text { Six-month follow-up of } \\
\text { cervical composite } \\
\text { restorations placed with a } \\
\text { new universal adhesive } \\
\text { system: a randomized } \\
\text { clinical trial }\end{array}$ & $\begin{array}{l}\text { Randomized, double-blind, } \\
\text { prospective study }\end{array}$ & Permanent & $2,6,11,12$ & 5 & $\begin{array}{c}\text { Modified } \\
\text { USPHS criteria }\end{array}$ & Trained on photographs \\
\hline $\begin{array}{l}\text { Luque- } \\
\text { Martinez et al } \\
{[28]}\end{array}$ & 2015 & $\begin{array}{c}\text { Effect of EDTA } \\
\text { conditioning on cervical } \\
\text { restorations bonded with } \\
\text { a self-etch adhesive: a } \\
\text { randomized double-blind } \\
\text { clinical trial }\end{array}$ & $\begin{array}{l}\text { Randomized, double-blind, } \\
\text { prospective study }\end{array}$ & Permanent & $2,6,11,12$ & 5 & - & Calibrated \\
\hline $\begin{array}{l}\text { May et al } \\
\text { [29] }\end{array}$ & 2017 & $\begin{array}{l}\text { Flowable composites for } \\
\text { restoration of non-carious } \\
\text { cervical lesions: three- } \\
\text { year results }\end{array}$ & $\begin{array}{l}\text { Randomized, prospective } \\
\text { study }\end{array}$ & Permanent & $1,2,5,6,11$ & 5 & - & Calibrated \\
\hline $\begin{array}{c}\text { Mena-Serrano } \\
\text { et al } \\
{[30]}\end{array}$ & 2013 & $\begin{array}{c}\text { A new universal } \\
\text { simplified adhesive: } 6- \\
\text { month clinical evaluation }\end{array}$ & $\begin{array}{l}\text { Randomized, prospective } \\
\text { study }\end{array}$ & Permanent & $2,5,6,11,12$ & 5 & $\begin{array}{c}\text { Modified } \\
\text { USPHS criteria }\end{array}$ & Trained on photographs \\
\hline
\end{tabular}




\begin{tabular}{|c|c|c|c|c|c|c|c|c|}
\hline $\begin{array}{l}\text { Metz et al } \\
\quad[31]\end{array}$ & 2015 & $\begin{array}{c}\text { Risk factors for } \\
\text { secondary caries in direct } \\
\text { composite restorations in } \\
\text { primary teeth }\end{array}$ & Retrospective study & Primary & $\begin{array}{l}12 \text { criteria used without } \\
\text { any precision }\end{array}$ & $\begin{array}{c}\text { No } \\
\text { precision }\end{array}$ & - & - \\
\hline $\begin{array}{c}\text { Montagner et } \\
\text { al } \\
{[32]}\end{array}$ & 2015 & $\begin{array}{l}\text { Effect of pre-treatment } \\
\text { with chlorhexidine on the } \\
\text { retention of restorations: } \\
\text { a randomized controlled } \\
\text { trial }\end{array}$ & $\begin{array}{l}\text { Randomized, triple-blind, } \\
\text { prospective study } \\
\text { Split-mouth design }\end{array}$ & Permanent & $1-6,11,13,14$ & 5 & - & $\begin{array}{l}\text { Trained/calibrated on E- } \\
\text { calib }\end{array}$ \\
\hline $\begin{array}{l}\text { Perdigao et al } \\
\text { [33] }\end{array}$ & 2014 & $\begin{array}{c}\text { A new universal } \\
\text { simplified adhesive: } 18- \\
\text { month clinical evaluation }\end{array}$ & $\begin{array}{l}\text { Randomized, prospective } \\
\text { study }\end{array}$ & Permanent & $2,5,6,11,12$ & 5 & $\begin{array}{c}\text { Modified } \\
\text { USPHS criteria }\end{array}$ & Trained on photographs \\
\hline $\begin{array}{l}\text { Sengul et al } \\
\text { [34] }\end{array}$ & 2015 & $\begin{array}{c}\text { Clinical evaluation of } \\
\text { restorative materials in } \\
\text { primary teeth class II } \\
\text { lesions }\end{array}$ & $\begin{array}{l}\text { Randomized, prospective } \\
\text { study }\end{array}$ & Primary & $1-6,8-16$ & 5 & - & - \\
\hline $\begin{array}{l}\text { Skupien et al } \\
\text { [35] }\end{array}$ & 2016 & $\begin{array}{l}\text { Crown vs. composite for } \\
\text { post-retained restorations: } \\
\text { a randomized clinical } \\
\text { trial }\end{array}$ & $\begin{array}{l}\text { Randomized, prospective } \\
\text { study }\end{array}$ & Permanent & $1-16$ & 5 & - & Trained and calibrated \\
\hline $\begin{array}{l}\text { Staehle et al } \\
\text { [36] }\end{array}$ & 2015 & $\begin{array}{l}\text { A } 6.5 \text {-year clinical } \\
\text { follow-up of direct resin } \\
\text { composite buildups in the } \\
\text { posterior dentition: } \\
\text { introduction of a new } \\
\text { minimally invasive } \\
\text { restorative method }\end{array}$ & Retrospective study & Permanent & $1-7,10-12,14$ & 3 & $\begin{array}{c}\text { Modified } \\
\text { USPHS criteria }\end{array}$ & $\begin{array}{l}\text { Trained/calibrated on E- } \\
\text { calib }\end{array}$ \\
\hline $\begin{array}{c}\text { Walter } \text { et al } \\
\text { [37] }\end{array}$ & 2014 & $\begin{array}{l}\text { Three-year clinical } \\
\text { evaluation of a silorane } \\
\text { composite resin }\end{array}$ & $\begin{array}{l}\text { Randomized single-blind } \\
\text { clinical study }\end{array}$ & Permanent & $1-16$ & 5 & - & - \\
\hline $\begin{array}{l}\text { Zander- } \\
\text { Grande et al } \\
\quad[38]\end{array}$ & 2014 & $\begin{array}{l}\text { Clinical performance of } \\
\text { one-step self-etch } \\
\text { adhesives applied } \\
\text { actively in cervical } \\
\text { lesions: } 24 \text {-month clinical } \\
\text { trial }\end{array}$ & $\begin{array}{l}\text { Randomized, prospective } \\
\text { study }\end{array}$ & Permanent & $2,5,6,11,12$ & 5 & - & Trained on photographs \\
\hline
\end{tabular}


Table 4: The use of FDI criteria per year since 2007

\begin{tabular}{|c|c|c|c|}
\hline Year & $\begin{array}{c}\text { Total number of } \\
\text { studies }\end{array}$ & $\begin{array}{l}\text { Number of studies } \\
\text { using FDI criteria }\end{array}$ & $\begin{array}{l}\% \text { of studies using } \\
\text { FDI criteria }\end{array}$ \\
\hline $\begin{array}{c}\text { Total (published } \\
\text { studies) }\end{array}$ & 184 & 30 & 16.3 \\
\hline 2007 & 18 & 0 & 0 \\
\hline 2008 & 10 & 0 & 0 \\
\hline 2009 & 16 & 0 & 0 \\
\hline 2010 & 22 & 1 & 4.6 \\
\hline 2011 & 14 & 2 & 14.3 \\
\hline 2012 & 14 & 1 & 7.1 \\
\hline 2013 & 19 & 3 & 15.8 \\
\hline 2014 & 20 & 4 & 20 \\
\hline 2015 & 31 & 10 & 32.3 \\
\hline 2016 & 14 & 7 & 50 \\
\hline 2017 & 6 & 2 & 3.3 \\
\hline Ongoing studies & 27 & 14 & 51.9 \\
\hline $\begin{array}{l}\text { - with a close } \\
\text { recruitment status }\end{array}$ & 19 & 7 & 36.8 \\
\hline $\begin{array}{l}\text { - with an open } \\
\text { recruitment status }\end{array}$ & 8 & 7 & 87.5 \\
\hline $\begin{array}{c}\text { Total } \\
\text { (published + } \\
\text { ongoing studies) }\end{array}$ & 211 & 44 & 68.2 \\
\hline
\end{tabular}

